\title{
Prebiotic Potential of Oligosaccharides: In Vitro Study of Indonesian Local Honey from Apis spp. and Trigona spp. Bees
}

\author{
Fitria Susilowati ${ }^{1, *}$, Mita Nurul Azkia ${ }^{2}$ \\ ${ }^{1}$ Program Studi Gizi, Universitas Islam Negeri Walisongo, Semarang, 50185, Indonesia \\ ${ }^{2}$ Program Studi Teknologi Hasil Pertanian, Universitas Semarang, Semarang, 50196, Indonesia \\ *Corresponding author.Email: fitria_susilowati@walisongo.ac.id
}

\begin{abstract}
Oligosaccharide compounds (FOS, GOS) have gained huge commercial interest due to their beneficial properties in human health as prebiotics. This study aims to isolate the oligosaccharides compounds and investigate the prebiotic potential of Indonesian local honey from Apis spp. (KR) and Trigona spp. (KL) honey bees. The isolation of oligosaccharides was done utilizing the adsorption activity of activated carbon. The qualitative assay to investigate the oligosaccharides was performed by TLC (Thin Layer Chromatography) method. The isolated oligosaccharides was determined quantitatively by the Phenol-Sulphuric Acid method (Total Sugar) and dinitrosalicylic acid (DNS) methods (Reducing Sugar). The total sugar content from oligosaccharides of KR and KL were 1287.82 $\pm 3.11 \mathrm{mg} / \mathrm{L}$ and $336.54 \pm 0.00 \mathrm{mg} / \mathrm{L}$ respectively. The reducing sugar content from oligosaccharides of $\mathrm{KR}$ and KL were $387.33 \pm 8.08$ $\mathrm{mg} / \mathrm{L}$ and $144.67 \pm 8.08 \mathrm{mg} / \mathrm{L}$. The in vitro analysis of prebiotic activity was performed by Bacterial Growth Assay and Total Plate Counting from Lactobacillus acidophilus and Bifidobacterium longum on each 0, 24, and 48 hours. The Total Plate Counting showed that the maximum bacterial growth on Lactobacillus acidophilus for KR was $(8.00 \pm 0.28)$ $108 \mathrm{cfu} / \mathrm{mL}$ after 24 hours and (7.35 \pm 0.78$) 108 \mathrm{cfu} / \mathrm{mL}$ for KL after inoculated for 48 hours.
\end{abstract}

Keywords: Oligosaccharides, Prebiotic, Honey, Apis spp., Trigona spp.

\section{INTRODUCTION}

Over the decades, numerous studies have listed prebiotic as a health promoting element. Scientific facts have been proved great benefits of prebiotic, i.e. stimulating the growth of gut microflora [1], mineral absorption enhancer [2], cholesterol lowering agent [3], immune enhancer and antipathogenic [4], even as an anticancer agent [5]. Prebiotic is naturally found in food and mostly classified as oligosaccharides, namely Fructo-oligosaccharides (FOS) and Galactooligosaccharides (GOS).

One of the abundant sources of prebiotic oligosaccharides is in honey. Honey is an example of a complex carbohydrate with the largest content of monosaccharides, namely fructose $(38.5 \%)$ and glucose (31.0\%). Other components are oligosaccharides (4.2\%), minerals and enzymes $(0.5 \%)$, and also water $(17.1 \%)$ [6]. A total of 30 types of polysaccharide compounds are found in honey. The prebiotic properties of honey had been validated by successfully stimulating the growth of fecal bacteria Bifidobacterium spp. [7-9]. These results were concluded due to the present of oligosaccharides in honey at levels of 4 to 5\%. Sanz et al. [9] managed to isolate oligosaccharide of Spain honeydew honey with activated charcoal method. The oligosaccharides were reported to display potential prebiotic activity by increasing the number of Bifidobacteria and Lactobacilli using an in vitro fermentation system. Furthermore, isolated oligosaccharides from local honey of Sumbawa Island have also shown to increase the population of $\mathrm{L}$. acidophilus [10].

Apis spp., subspecies Apis mellifera and Apis cerana, is the major bee species that produces the most honey in Indonesia. Approximately $25-35 \mathrm{~kg}$ honey is produced from a colony per year [11]. Due to its high productivity, Apis spp. is being cultivated for beekeeping activities (apiculture) mainly in Pati Regency, Central Java. Pati Regency has now become the government's priority for the central apiculture area in Java due to its high biodiversity. The vast area of Kapok Tree (Ceiba 
pentandra) in Pati Regency produces mostly unifloral honey from Apis spp., namely Kembang Randu, which has unique characteristic in color, aroma, and taste. Unlike Kembang Randu honey, Klanceng or Kelulut honey is produced by Trigona spp., subspecies Trigona clypearis and Trigona sapiens, small stingless bees from multifloral origin. Trigona spp. colony are naturally found in the hollow of bamboos or trees. Instead of being stored in a hexagonal honeycombs, Trigona spp. bees store their honey in resin pots, which is a mixture of propolis. This is what gives Klanceng or Kelulut honey a unique characteristic, which is watery, light brown, and much sour in taste.

The Naturally occurring oligosaccharides in honey depend on its floral origin. Thus, the purpose of this study was to isolate the oligosaccharides of Indonesian local honey from Apis spp. (KR) and Trigona spp. (KL) honey bees. Furthermore, the prebiotic activity was investigated in vitro on growth of predominant intestinal microflora, Lactobacillus acidophilus and Bifidobacterium longum.

\section{MATERIALS AND METHOD}

\subsection{Materials}

The honey samples, Kembang Randu (KR) and Klanceng (KL) honey, were directly obtained from the beekeepers community, respectively in Gunungwungkal and Gembong District, Pati Regency (Central Java, Indonesia).

The solvent used for general purposes were commercial grade; Merck Pro-Analysis (MerckGermany): Ethanol (EtOH), Methanol (MeOH), Butanol $(\mathrm{BuOH})$, Sulfuric acid $\left(\mathrm{H}_{2} \mathrm{SO}_{4}\right) 96 \%$ reagent grade, and Pyridine. Standard substances used were analytical standards (Sigma-USA): Sodium hydroxide $(\mathrm{NaOH})$, 3,5-dinitrosalicylic acid (DNS), N-(1Naphthyl)ethylenediamine dihydrochloride, fructose, glucose, maltose, phenol, and Sodium-Potassium tartrate.

Thin-layer chromatography (TLC) was performed on silica gel $60 \mathrm{~F}_{254}(0.20 \mathrm{~mm}$ thickness). The in vitro analysis of prebiotic activity (Bacterial Growth Assay and Total Plate Counting) were carried out with media MRSB (Oxoid Ltd, UK) consist of Glucose (D(+)glucose Merck) $20 \mathrm{~g} / 2 \%$, yeast extract (Bacto TM Yeast Extract) $4 \mathrm{~g} / 0,4 \%$, beef extract, Bacto peptone (BBL TM Polypeptone TM Peptone) $10 \mathrm{~g} / 1 \%$, sodium asetat 5 $\mathrm{g} / 0,5 \%, 10 \mathrm{~g} / 1 \%$, sodium asetat $5 \mathrm{~g} / 0,5 \%, \mathrm{~K}_{2} \mathrm{H}_{2} \mathrm{PO}_{4} 2$ $\mathrm{g} / 0,2 \%, \quad \mathrm{MgSO}_{4} .7 \mathrm{H}_{2} \mathrm{O}, 0,05 \mathrm{~g} / 0,005 \%$, ammonium citrate tribune $2 \mathrm{~g} / 0,2 \%$, Tween $801 \mathrm{~mL} / 0,1 \%$ and agar powder (American Bacteriological Agar) 2\%. Human intestinal bacteria used were Lactobacillus acidophilus (ATCC 15708) and Bifidobacterium longum (ATCC 4356).

\subsection{Isolation of oligosaccharides}

The isolation procedure was carried out following the method of Morales et al. [12] with several modifications. Briefly, $500 \mathrm{mg}$ of honey and $3 \mathrm{~g}$ of activated charcoal, Darco $\mathrm{G}_{60}, 100$ mesh (Sigma-Aldrich), were dissolved in $100 \mathrm{~mL}$ of EtOH $10 \%$ (v/v) then stirred for $30 \mathrm{~min}$. This mixture was filtered through Whatman No. 1 paper (Whatman International Ltd., Maidstone, UK) under vacuum and the activated charcoal was washed with 25 $\mathrm{mL}$ of EtOH $10 \%$ (v/v). Desorption of oligosaccharides from the activated charcoal was carried out with $100 \mathrm{~mL}$ of ethanol $(50 \%, \mathrm{v} / \mathrm{v})$. The mixture was stirred for $30 \mathrm{~min}$ and filtered as previously described. The filtrates evaporated under vacuum at $40^{\circ} \mathrm{C}$.

\subsection{Identification of oligosaccharides}

The oligosaccharides were identified qualitatively by Thin-layer chromatography (TLC). The sample was dissolved in $50 \% \mathrm{EtOH}$ with a concentration of $5 \%$ (w/v), carbohydrate standards were made at a concentration of $1 \%(\mathrm{w} / \mathrm{v})$. The sample $(10 \mu \mathrm{L})$ was spotted onto a TLC plate on a line about $1.5 \mathrm{~cm}$ above the lower plate edge. The plate was then eluted with a pyridine: $\mathrm{BuOH}$ :water (4:6:3 v/v) solvent mixture [13]. To render sugars visibility, plate was sprayed to saturation with a solution containing $\quad 0.3 \mathrm{~g} / 100 \mathrm{~mL}$ of $\mathrm{N}^{*}$ (1-naphthyl) ethylenediamine dihydrochloride in a solvent system composed of $\mathrm{MeOH}: \mathrm{H}_{2} \mathrm{SO}_{4}(97: 3 \mathrm{v} / \mathrm{v})$ according to Bounias (1980) [14]. The plate was then heated in a 120 $140{ }^{\circ} \mathrm{C}$ oven (vented to exhaust hood) until spots were visible (approximately $8-10 \mathrm{~min}$ ). The Retention factors (Rf) were then calculate following the formula:

$$
R f=\frac{\text { distance travelled by the compound }}{\text { distance travelled by solvent front }}
$$

\subsection{Determination of Total Sugar (Phenol- Sulphuric Acid Method)}

Total sugar content of the sample was determined using Phenol-Sulphuric Acid method according to Dubois et al. (1956) [15]. Phenol in the presence of sulphuric acid can be used for the quantitative colorimetric determination of total sugar including simple sugars, oligosaccharides, polysaccharides, and their derivatives. As a result, it will give a stable orangeyellow color.

In brief, $1 \mathrm{~g}$ of glucose was dissolved in $1 \mathrm{~L}$ aquadest to prepare a stock solution of $1000 \mathrm{mg} / \mathrm{L}$. The stock was then diluted to make a working standard solution of glucose 20, 40, 60, 80, and $100 \mathrm{mg} / \mathrm{L}$ respectively. Each $0,5 \mathrm{~mL}$ of working standard solution in a tube was added with $0,5 \mathrm{~mL}$ phenol $5 \%(\mathrm{w} / \mathrm{v})$. Then $2,5 \mathrm{~mL}$ of concentrated $\mathrm{H} 2 \mathrm{SO} 4$ added rapidly; the stream of acid 
being directed against the liquid surface rather than against the side of the test tube in order to obtain good mixing. The tubes were then vortexed for 10 minutes and placed for 20 minutes in a water bath at $25-30{ }^{\circ} \mathrm{C}$. The absorbance measured with a spectrophotometer at a wavelength of $490 \mathrm{~nm}$, then the linear equation was made as a standard curve. Blanks are prepared by substituting distilled water for the sugar solution. All solutions are prepared in triplicate to minimize errors.

Sample measurement was carried out in a similar manner by using $0.5 \mathrm{~mL}$ of the sample solution as a substitute for the sugar solution. The absorbance value obtained is plotted on a standard curve and the amount of total sugar present in the sample solution was then calculated.

\subsection{Determination of Reducing Sugar (DNS Method)}

The DNS method is the common method for determining reducing sugar according to Miller (1959) [16]. This method utilizes 3,5-dinitrosalicylic acid which can detect the presence of free carbonyl group $(\mathrm{C}=\mathrm{O})$ of reducing sugars. This involves the oxidation of the aldehyde functional group (in glucose) and the ketone functional group (in fructose). During this reaction DNS is reduced to 3-amino-5-nitrosalicylic acid which under alkaline conditions is converted to an orange-red colored complex (Figure 1).

To prepare a DNS solution, $1 \mathrm{~g}$ of DNS powder was dissolved into $20 \mathrm{~mL}$ of $\mathrm{NaOH} 2 \mathrm{M}$, and $30 \mathrm{~g}$ of $\mathrm{Na}-\mathrm{K}$ tartrate was added subsequently up to $100 \mathrm{~mL}$. The solution was then stood in the chiller.

The stock solution prepared was a glucose solution $1000 \mathrm{mg} / \mathrm{L}$. The stock was then diluted to make a working standard solution of glucose $0,20,40,60,80$, and $100 \mathrm{mg} / \mathrm{L}$ respectively. Each $1 \mathrm{~mL}$ of working standard solution in a tube was added with $1 \mathrm{~mL}$ of DNS solution and $2 \mathrm{~mL}$ of aquadest. The tubes were then vortexed for 10 minutes. The absorbance was measured with a spectrophotometer at a wavelength of $540 \mathrm{~nm}$, then the linear equation was made as a standard curve. Blanks are prepared by substituting distilled water for the sugar solution. All solutions are prepared in triplicate to minimize errors.

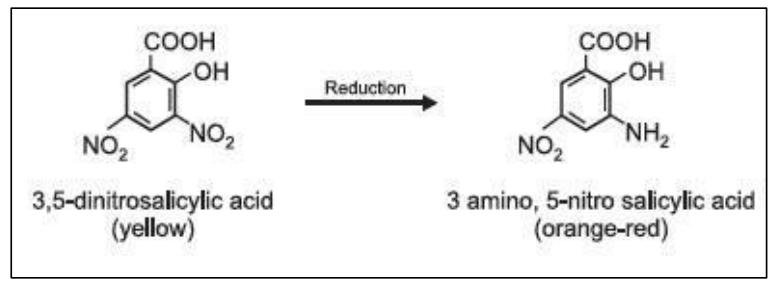

Figure 1 Chemical Reaction for DNS Method
Sample measurement was carried out in a similar manner by using $1 \mathrm{~mL}$ of the sample solution as a substitute for the sugar solution. The absorbance value obtained is plotted on a standard curve and the amount of total sugar present in the sample solution was then calculated.

\subsection{In Vitro Bacterial Growth Assay}

The in vitro bacterial growth assay was performed by analyzing the growth of Lactic Acid Bacteria (LAB), Lactobacillus acidophilus and Bifidobacterium longum. This assay is a modification of the bacterial growth assay by AOAC (2005) [17] and USDA-APHIS (2015) [120]. The considerable parameters are, turbidimetric optical density (OD), the number of colonies by Total Plate Count (TPC), and $\mathrm{pH}$ measurement.

\subsubsection{Turbidimetric Optical Density (AOAC 2005)}

Two types of Lactic Acid Bacteria (LAB), Lactobacillus acidophilus and Bifidobacterium longum were inoculated on de Mann Rogosa Sharpe Broth (MRSB) media. A total of $0.5 \mathrm{~mL}$ of oligosaccharide isolate was added to a tube containing $9 \mathrm{~mL}$ of sterile MRSB aseptically. One mL of Lactobacillus acidophilus was pipetted to the MRSB, and aquadest was added up until $15 \mathrm{~mL}$ in total. The tube was then homogenized using a shaker. Absorbance or optical density (OD) was measured by spectrophotometry, spectrophotometer UVVis Double Beam Aquamate Thermo Scientific, at a wavelength of $660 \mathrm{~nm}$ at 0,24 , and 48 hours.

The procedure for Bifidobacterium longum was done in a similar manner. The treatments are mapped as follows:

1) $\mathrm{K}(-) \quad$ : MRSB as a negative control

2) $\mathrm{K}(+) \quad$ : MRSB $+\mathrm{LAB}$ as a positive control

3) $\mathrm{KR}:$ MRSB + LAB + oligosaccharides isolate of $\mathrm{KR}$ honey

4) $\mathrm{KL}:$ MRSB + LAB + oligosaccharides isolate of KL honey

The oligosaccharides isolate would affect the growth of LAB. The higher growth of LAB, the higher OD value would be produced. Based on the optical density (OD) results, one $\mathrm{LAB}$ was selected to be tested for Total Plate Counting (TPC). This indicates that the oligosaccharides isolate has a positive effect on the growth of LAB.

\subsubsection{Total Plate Counting (USDA-APHIS, 2015)}

One $\mathrm{mL}$ of sample with higher OD produced, was taken to be inoculated on the MRS agar plate using the spread plate method, subsequently incubated at $37^{\circ} \mathrm{C}$ for 
48 hours (aerobic). The number of colonies was calculated and expressed in logarithmic colony forming units/mL $(\log \mathrm{cfu} / \mathrm{mL})$.

\subsubsection{Measurement of $\mathrm{pH}$}

The degree of acidity $(\mathrm{pH})$ was measured in each treatment of oligosaccharide isolates after incubation periods of 0,24 , and 48 hours using a pH meter. LAB that grows utilizing oligosaccharide isolates would produce lactic acid compounds in the growing media, so that the growth media would be acidic $(\mathrm{pH}<7)$.

\subsection{Data Analysis}

Data analysis used was one way ANOVA to determine any statistically significant differences between the means of the two honey oligosaccharides with the significance degree to $5 \%(\mathrm{p}<0.05)$.

\section{RESULTS AND DISCUSSION}

\subsection{Characterization of Honey Oligosaccharides}

The area of Gunungwungkal is one of the largest honey bee farms in Pati Regency, Central Java. The local honey, Kembang Randu (KR), is produced from Apis mellifera and Apis cerana colony in Kapok Tree (Ceiba pentandra) unifloral forest area. The honey has a clear and thick brown color with a distinctive sweet taste of honey. Meanwhile, the Klanceng (KL) honey was obtained from Gembong, Pati Regency. Klanceng honey is produced by Trigona sapiens and Trigona clypearis small bees. The size of the Trigona spp. is even smaller than flies (Musca domestica). Trigona spp. is belong to Meliponini (Family of Apidae) are also called "stingless bees' '. Meliponini is closely related to the honey bees, Apini, both belong to the family of Apidae [21]. Trigona spp. colonies are naturally found in the hollow of bamboos in the multifloral forest area. This natural habitat gives Klanceng honey a unique characteristic, which is watery, light brown, and much sour in taste. Aso et al. [13] classified the colors of honey (brown, dark brown, light brown, pale brown, pale yellow and yellow) partly due to differences in nectar sources (National Honey Board). Anklam [20] added several other factors that affect the color difference of honey, namely mineral content, phenolic compound, and storage process. Darker or deep color of honey indicates higher levels of phenolic compounds and mineral contents. Whereas storage process would change honey to have a darker colour due to hydrolyzation of honey monosaccharides and form 5hydroxymethylfurfural (HMF) which then turns into phenolic compounds.
The isolation of oligosaccharides was carried out by adsorption method using activated carbon as an adsorbent. Activated carbon was added to the honey which was dissolved in $10 \%$ ethanol and stirred for 30 minutes. Ethanol solution helps to extract the oligosaccharides which will then be adsorbed by activated carbon. Activated carbon utilizes the Van Der Waals attraction to adsorb oligosaccharide compounds. The big size of the oligosaccharide molecule strengthens the intermolecular forces. The adsorbed oligosaccharides were then desorbed with a more concentrated ethanol $(50 \% \mathrm{EtOH}, \mathrm{v} / \mathrm{v})$. Activated carbon has a large surface area and pore volume, thereby increasing its adsorption ability. Beside, it is a high availability adsorbent, which is widely used and affordable. Bao et al. [21] showed that the adsorption power of activated carbon on raffinose $(0.60 \sim 0.65 \mathrm{~g} / \mathrm{g})$ was higher than that on sucrose $(0.35 \sim 0.40 \mathrm{~g} / \mathrm{g})$. Raffinose is an oligosaccharide compound. Activated carbon shows good affinity for oligosaccharides and is able to separate raffinose from sucrose. The isolates were produced after the filtrate was evaporated under vacuum using a rotary evaporator at a temperature of $40^{\circ} \mathrm{C}$. The isolated oligosaccharides of Kembang Randu (KR) honey was glossy yellow in color and yielded $3.97 \%$. The glossy color was produced due to the caramelization process of sugar. The oligosaccharide isolate from Klanceng (KL) honey was clear yellowish in color and yielded $2.22 \%$ of rendement (Table 1).

Table 1. Characterization of Honey Oligosaccharides

\begin{tabular}{|c|l|l|l|}
\hline $\begin{array}{c}\text { N } \\
\text { o }\end{array}$ & $\begin{array}{c}\text { Types of } \\
\text { Honey }\end{array}$ & $\begin{array}{c}\text { Rendemen } \\
\mathbf{t}\end{array}$ & $\begin{array}{c}\text { Physical } \\
\text { Characterization }\end{array}$ \\
\hline 1 & KR & $3.97 \%^{*}$ & Glossy yellow \\
\hline 2 & KL & $2.22 \%^{*}$ & Clear yellow \\
\hline
\end{tabular}

- Rendement obtained per 0.5 gram of sample

The isolated oligosaccharides were identified using the TLC method. The standard monosaccharides used were glucose and fructose, while maltose is used for the standard of disaccharides. The standard sugars and samples were dissolved in volatile ethanol, so that it leaves behind a small spot at the stationary phase ( $\mathrm{Si}$ gel plate Merck $60 \mathrm{~F}_{254}$ ). The mobile phase (eluent) used was a mixture of pyridine:butanol:water $(4: 6: 3 \mathrm{v} / \mathrm{v})$ solvents. This polarity rate succeeds in identifying oligosaccharides in 22 types of honey [13]. The eluent then travels up the plate by capillary action, which moves over the spot from the starting point. The Retention factor $\left(R_{f}\right)$ value is used to quantify the movement of the materials along the plate. The $R_{f}$ is equal to the distance traveled by the substance divided by the distance traveled by the solvent. 


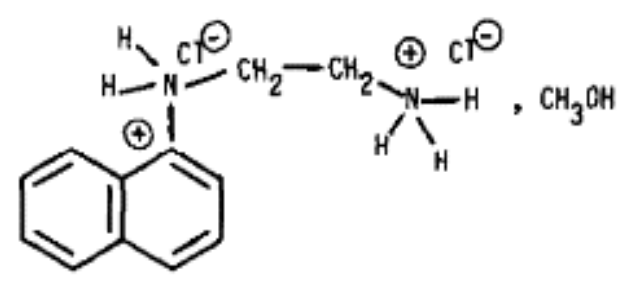

Figure $2 \mathrm{C}_{10} \mathrm{H}_{7} \mathrm{C}_{2} \mathrm{H}_{4} \mathrm{~N}_{2} \mathrm{H}_{5} \mathrm{Cl}_{2}, \quad \mathrm{CH}_{3} \mathrm{OH}$ (Molecular weight: 291.22)

Spot visualization was performed by immersing the dried TLC plate with a solution containing $\mathrm{N}^{*}(1-$ naphthyl) ethylenediamine dihydrochloride in a solvent system consisting of $\mathrm{MeOH}: \mathrm{H}_{2} \mathrm{SO}_{4}$. The temperature strongly accelerates the activation of amine radicals which then undergoes dehydration reactions between the $\mathrm{N}$-hydrogens and the hydroxyl groups of sugars (Figure 2) [14].

The chromatograms, as shown on Figure 3, were compared to raw honey KR and KL. The standard sugars (glucose, fructose, and maltose) have a definite $\mathrm{Rf}$ value $0.73,0.68$, and 0.63 , respectively. It was recognized that the amount of sugars in raw honey KR and KL were not the same $(\mathrm{KL}<\mathrm{KR})$, but the types of sugar were almost the same. The oligosaccharides were managed to be isolated, although there are still low levels of mono- and disaccharides. This could be seen from the forming of low-intensity tailing spots. In general, the isolated oligosaccharides of honey are in the form of raffinose, isomaltose, maltotriose melezitose, panose, and kestose [22].
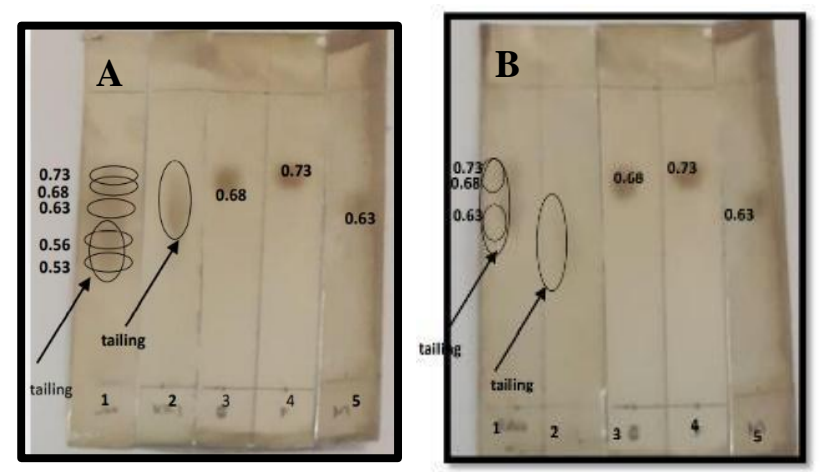

Figure 3. Chromatograms of isolated oligosaccharides: (A) KR honey; (B) KL honey. (3) Standard of glucose; (4) Standard of fructose; (5) Standard of maltose. A(1) KR raw honey; $\mathrm{A}(2)$ isolated oligosaccharides of $\mathrm{KR}$ honey. $\mathrm{B}(1) \mathrm{KL}$ raw honey; $\mathrm{B}(2)$ isolated oligosaccharides of KL honey.
Raw honey KR produced five spots that are clearly visualized at $\mathrm{Rf} 0.73,0.68,0.63 .0 .56$, and 0.53 . It was recognized that the spots of $0.73,0.68$, and 0.63 were glucose, fructose, and maltose, respectively. This shows that the largest sugar composition in raw honey KR is a mixture of glucose and fructose, monosaccharides. Spots with $R_{\mathrm{f}} 0.56$ and 0.53 were predicted to be the most abundant oligosaccharides in KR honey. The isolated oligosaccharides of KR honey produced low-intensity tailing spots. This is due to various types of oligosaccharides creating overlapping (tailing) spots one to another. These tailings spots were calculated to have Rf values of standard sugars, at $R_{f}$ of $0.73,0.68$, and 0.63 . The low-intensity spot also recognized that the amount of sugars in isolated oligosaccharides were lesser than that of in raw honey KR.

Raw honey KL produced 3 spots which were clearly visualized at $R_{f} 0.73,0.68$, and 0.63 . It is known that the spots were standard sugars. Thus, makes them the largest component of raw honey KL. The isolated oligosaccharides of KL honey also produced lowintensity tailing spots. This low-intensity spot also recognized that the amount of oligosaccharide compounds were not as much as the composition of glucose or fructose (monosaccharide). Based on the $R_{f}$ value, these isolated oligosaccharides succeeded to separate glucose and fructose, but still have low levels of maltose.

Both chromatograms displayed the main components of raw honey KR and KL were relatively same, which is monosaccharide compounds. Raw honey KR has a higher amount of glucose and fructose than raw honey KL. This is indicated by the thicker spot KR A(1) on the plate. In addition, both oligosaccharide spots, KR A(2) and KL $\mathrm{B}(2)$ were tailing spots. This mostly due to the wide types of low levels carbohydrates are exist in honey, hence the spot boundaries are difficult to be specified.

\subsection{Total Sugar Content of Honey Oligosaccharides.}

The Total Sugar content of KR and KL honey oligosaccharide were determined by Phenol- Sulphuric Acid Method. This method is a colorimetric method that utilizes acidic phenol to react with honey oligosaccharide. Concentrated sulphuric acid solution hydrolyzes oligosaccharide compounds and hydrates them, so that furfural compounds will then form. The furfural compounds which then react with phenol to produce a yellowish orange color. The color formed was analyzed using UV-Vis Spectrophotometer at a maximum absorbance $490 \mathrm{~nm}$, then the linear equation was made as a standard linear curve (Figure 4). 


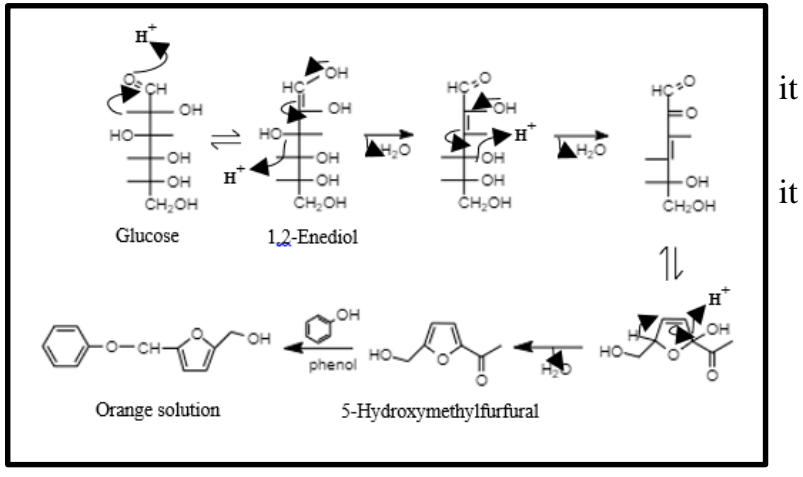

Figure 4 Chemical Reaction of glucose with PhenolSulphuric Acid Reagent

The linear equation obtained from the measurement of the absorbance of the glucose standard solution is $\mathrm{y}=$ $0.0013 \mathrm{x}-0.0145(\mathrm{R} 2=0.988)$. The average absorbance value of the oligosaccharide was plotted on a standard curve $(\mathrm{KR}=0.225 \mathrm{~A} ; \mathrm{KL}=0.048 \mathrm{~A})$, so that the total sugar of the KR oligosaccharide was $1287.82 \pm 3.11 \mathrm{mg} / \mathrm{L}$ with a percentage of $40.77 \%$. Meanwhile, the total sugar content of KL oligosaccharide was $336.54 \pm 0.00 \mathrm{mg} / \mathrm{L}$ with a percentage of $11.20 \%$. Based on these data, it can be proved that the total sugar content of the KR oligosaccharide was higher than that of KL. This explains why KR honey has a sweeter taste compared to KL honey. In regards to previous study, the stingless bee honey is purported to be low in sugar, especially glucose (8.10-31.00\%), one third lower than original Apis spp. honey.

\subsection{Reducing Sugar Content of Honey Oligosaccharides}

Honey is a concentrated solution of reducing sugars such as fructose and glucose. The reducing sugar content of KR and KL honey oligosaccharide were determined by the DNS method. This method utilizes 3,5dinitrosalicylic acid which can detect the presence of free carbonyl group $(\mathrm{C}=\mathrm{O})$ of reducing sugars. This involves the oxidation of the aldehyde functional group (in glucose) and the ketone functional group (in fructose), while the NO2 group in the DNS will be reduced. During this reaction DNS is reduced to 3-amino-5-nitrosalicylic acid which under alkaline conditions is converted to a orange-red colored complex, composed of UV-absorbing chromophore at $540 \mathrm{~nm}$ (Figure 5).

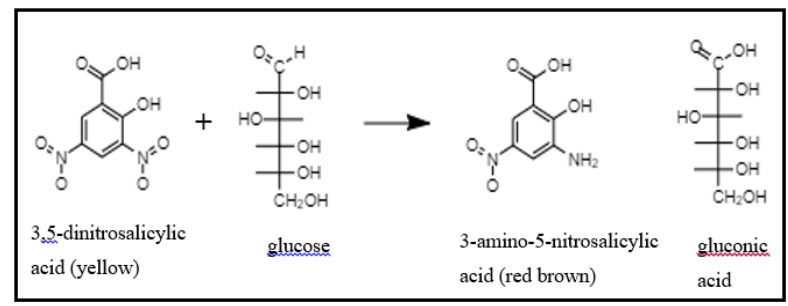

Figure 5 Chemical Reaction of Glucose with DNS Reagent
The linear equation obtained from the measurement of the absorbance of the glucose standard solution is $\mathrm{y}=$ $0.0005 x-0.003(\mathrm{R} 2=0.976)$. The average absorbance value of the oligosaccharide was plotted on a standard curve $(\mathrm{KR}=0.025 \mathrm{~A} ; \mathrm{KL}=0.008 \mathrm{~A})$, so that the reducing sugar content of the KR oligosaccharide was $387.33 \pm 8.08 \mathrm{mg} / \mathrm{L}$ with a percentage of $12.90 \%$. Meanwhile, the reduced sugar content of KL oligosaccharide was $144.67 \pm 8.08 \mathrm{mg} / \mathrm{L}$ with a percentage of $4.8 \%$ (Table 2). Based on these data, it can be proved that the reducing sugar content of the KR oligosaccharide was higher than that of KL.

Oligosaccharides are non-reducing sugars. However, some disaccharides are also non-reducing sugars. The oligosaccharides isolated from KR honey was 900.49 $\mathrm{mg} / \mathrm{L}(30.02 \%)$, while the oligosaccharides isolated from KL honey was $221.87 \mathrm{mg} / \mathrm{L}(7.39 \%)$. The high level of reducing sugars of KR oligosaccharide honey strengthened the spots visualization on chromatogram results (TLC). Different results were shown for the KL honey where the spots visualization of the reducing sugar was almost invisible $(7.39 \%)$. This study shows that oligosaccharides are at a more significant concentration after oligosaccharide isolation.

Table 2. Comparative Results of Total Sugar and Reducing Sugar Content Honey Oligosaccharides

\begin{tabular}{|l|l|l|}
\hline $\begin{array}{c}\text { Honey } \\
\text { Oligosaccha- } \\
\text { rides }\end{array}$ & $\begin{array}{c}\text { Total Sugar } \\
\text { content } \\
\text { (mg/L) }\end{array}$ & $\begin{array}{c}\text { Reducing } \\
\text { Sugar } \\
\text { Content } \\
\text { (mg/L) }\end{array}$ \\
\hline KR & $1287.82 \pm 3.11^{*}$ & $387.33 \pm 8.08^{*}$ \\
\hline KL & $336.54 \pm 0.00^{*}$ & $144.67 \pm 8.08^{*}$ \\
\hline
\end{tabular}

*The data are the average value \pm standard deviation with three repetitions $(\mathrm{p}<0.05)$.

\subsection{Study of Prebiotic Activity of Honey Oligosaccharides}

The prebiotic activity of honey oligosaccharides was determined in vitro by analyzing the growth of Lactic Acid Bacteria (LAB), Lactobacillus acidophilus and Bifidobacterium longum. Oligosaccharides are part of prebiotics that can stimulate the growth of gut microbiota. Each prebiotic source provides a diverse response to the growth of the gut microbiota. Absorbance or optical density (OD) of the growth media were measured $(\lambda=660 \mathrm{~nm})$ at incubation period 0,24 , and 48 hours on KR and KL oligosaccharides honey and control treatment (without the addition of honey oligosaccharide). The absorbance value of Lactobacillus acidophilus has increased in all treatments during incubation period 0-48 hours. This could be recognized from the cloudy spot formed on the growth media, indicating the growth of Lactobacillus acidophilus. The similar observation also obtained from to the growth of Bifidobacterium longum. Of all, the growth of 
Lactobacillus acidophilus was significantly increased higher to control, in comparison with the growth of Bifidobacterium longum (Table 3). The KR and KL honey oligosaccharide both can stimulate the growth of LAB, Lactobacillus acidophilus better than Bifidobacterium longum.

Prebiotics are food ingredients that provide carbohydrate substrates which can be fermented by probiotic strains selectively, thus it can benefit the health of the host by modulating the balance of intestinal microbes. Prebiotic carbohydrates are basically indigestible by pancreatic amylase and mucosal enzymes such as dextrinase and glucoamylase. Prebiotics play an important role in modifying the intestinal microflora which may have lost the dominance of Lactobacillus acidophilus and Bifidobacterium longum due to various factors such as dietary habits, medications, chronic stress, and aging factors. A good indicator of the effectiveness of prebiotics is their ability to resist the growth and activity of unwanted pathogens and other microflora, as well as support the growth of good bacteria (probiotics). This property is shown by the prebiotic activity of samples of KR and KL honey oligosaccharides.

Table 3. Absorbance Value of Bacterial Growth Assay $(\lambda=660 \mathrm{~nm})$

\begin{tabular}{|c|c|c|c|}
\hline \multirow{2}{*}{$\begin{array}{c}\text { Honey } \\
\text { Oligosacc } \\
\text { harides }\end{array}$} & \multirow{2}{*}{$\begin{array}{c}\text { Incubat } \\
\text {-ion } \\
\text { periods } \\
\text { (hours) }\end{array}$} & \multicolumn{2}{|c|}{ Absorbance Value of } \\
\hline & & $\begin{array}{l}\text { Lactobacillus } \\
\text { acidophilus }\end{array}$ & $\begin{array}{l}\text { Bifidobacteri } \\
\text { um longum }\end{array}$ \\
\hline \multirow{3}{*}{ Control } & 0 & $0.23 \pm 0.00^{\mathrm{aA}}$ & $1.00 \pm 0.00^{\mathrm{aA}}$ \\
\hline & 24 & $1.88 \pm 0.01^{\mathrm{bA}}$ & $1.66 \pm 0.00^{\mathrm{bA}}$ \\
\hline & 48 & $1.90 \pm 0.01^{\mathrm{bA}}$ & $1.68 \pm 0.01^{\mathrm{bA}}$ \\
\hline \multirow{3}{*}{$\mathrm{KR}$} & 0 & $0.40 \pm 0.02^{\mathrm{aB}}$ & $0.33 \pm 0.02^{\mathrm{aA}}$ \\
\hline & 24 & $1.89 \pm 0.01^{\mathrm{bB}}$ & $1.66 \pm 0.02^{\mathrm{bA}}$ \\
\hline & 48 & $1.95 \pm 0.06^{\mathrm{bB}}$ & $1.68 \pm 0.02^{\mathrm{bA}}$ \\
\hline \multirow{3}{*}{ KL } & 0 & $0.42 \pm 0.01^{\mathrm{aB}}$ & $0.33 \pm 0.01^{\mathrm{aA}}$ \\
\hline & 24 & $1.90 \pm 0.05^{\mathrm{bB}}$ & $1.65 \pm 0.01^{\mathrm{bA}}$ \\
\hline & 48 & $1.91 \pm 0.04^{\mathrm{bB}}$ & $1.68 \pm 0.02^{\mathrm{bA}}$ \\
\hline
\end{tabular}

The data are the average value \pm standard deviation with 3 repetitions. Different superscript notations showed significant differences between incubation periods. Different capital letters superscripts showed significant differences between treatments of honey oligosaccharides $(\mathrm{p}<0.05)$.
Data on LAB bacterial growth examined by Total Plate Counting are shown in Table 4. During the 48-hour incubation periods, the control showed an increase in the number of Lactobacillus acidophilus which is much less than KR and KL oligosaccharides honey. In control treatment, the number of colonies increased by $2.34 \%$; while in the KR oligosaccharides was given $25 \%$; and $\mathrm{KL}$ oligosaccharides was $15 \%$. As explained in the previous data, the absorbance value of the growth media of the two isolated oligosaccharides honey are higher than that of in control.

Table 4. Total Plate Counting (TPC) Value of Lactobacillus acidophilus

\begin{tabular}{|c|c|c|}
\hline $\begin{array}{c}\text { Honey } \\
\text { Oligosaccharides }\end{array}$ & $\begin{array}{c}\text { Incubation } \\
\text { periods } \\
\text { (hours) }\end{array}$ & $\begin{array}{c}\text { TPC Value } \\
\text { (cfu/ml) x 10 }\end{array}$ \\
\hline \multirow{3}{*}{ Control } & 0 & $6.40 \pm 0.28^{\mathrm{a}}$ \\
\cline { 2 - 3 } & 24 & $6.05 \pm 0.35^{\mathrm{ab}}$ \\
\cline { 2 - 3 } & 48 & $6.55 \pm 0.21^{\mathrm{b}}$ \\
\hline \multirow{3}{*}{ KR } & 0 & $6.40 \pm 0.28^{\mathrm{a}}$ \\
\cline { 2 - 3 } & 24 & $8.00 \pm 0.28^{\mathrm{ab}}$ \\
\cline { 2 - 3 } & 48 & $6.95 \pm 0.49^{\mathrm{b}}$ \\
\hline \multirow{3}{*}{ KL } & 0 & $6.40 \pm 0.28^{\mathrm{a}}$ \\
\cline { 2 - 3 } & 24 & $6.05 \pm 0.35^{\mathrm{ab}}$ \\
\cline { 2 - 3 } & 48 & $7.35 \pm 0.78^{\mathrm{b}}$ \\
\hline
\end{tabular}

The data are the average value \pm standard deviation with three repetitions. Different superscript notations showed significant differences between incubation periods. $(\mathrm{p}<0.05)$.

The presence of oligosaccharides could stimulate the growth of probiotic bacteria (LAB bacteria) with their metabolic products, namely short chain fatty acids (SCFA), such as butyric, acetic, and propionate acids. The presence of SCFA has been associated with the improvement of intestinal health, by lowering the $\mathrm{pH}$ of the colon, which leads to death to pathogenic microbes. The low $\mathrm{pH}$ of the colon due to the accumulation of SCFA suppresses the presence of pathogenic microbes in the colon, thereby reducing the risk of colon inflammation.

The $\mathrm{pH}$ of Lactobacillus acidophilus growth media is shown in Figure 6 . The $\mathrm{pH}$ value of the honey oligosaccharides at 48 hours shown to be lower than the 24 hours incubation. This indicates that the longer the incubation time, the lower the $\mathrm{pH}$ value. This is due to the accumulation of SCFA and most lactic acid as a byproduct of Lactobacillus metabolism. Figure 7 displayed the $\mathrm{pH}$ values of 24 hours incubation of Bifidobacterium longum on control, $\mathrm{KR}$, and $\mathrm{KL}$ oligosaccharides, 3.86, 3.9, and 3.89, respectively. While Lactobacillus acidophilus exhibited $\mathrm{pH}$ values of $3.84,3.9$, and 3.99, respectively on the control sample, $\mathrm{KR}$, and $\mathrm{KL}$ oligosaccharides (Figure 7). 


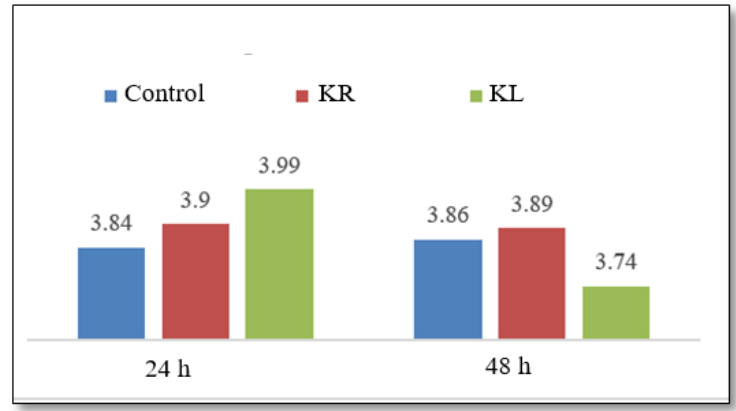

Figure 6 The $\mathrm{pH}$ of Lactobacillus acidophilus growth media

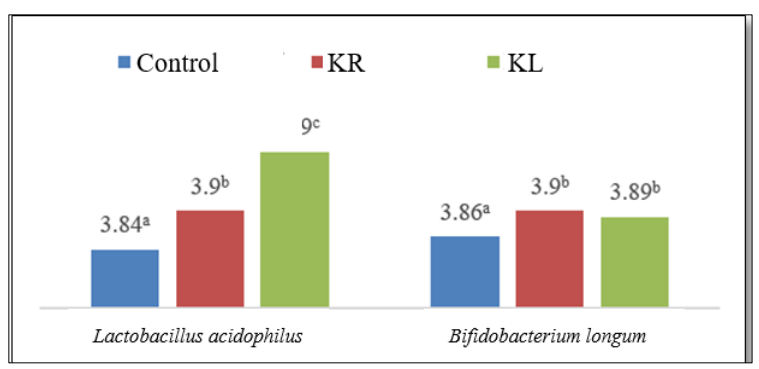

Figure 7 The $\mathrm{pH}$ value of Lactobacillus acidophilus Vs Bifidobacterium longum growth media (incubation period $24 \mathrm{~h}$ )

The prebiotic fermentation of these oligosaccharides honey produces SCFA that can reduce the $\mathrm{pH}$, thereby increasing the acidity of the intestinal environment as well as the energy reserve for intestinal epithelial cells. Lactic Acid Bacteria (LAB) such as Bifidobacterium longum and Lactobacillus acidophilus are common prebiotic targets. Promoting the growth of LAB resulting in production of bacteriocins, potential growth inhibitors of pathogenic bacteria. Oligosaccharides fermentation by $\mathrm{LAB}$ can also prevent colon cancer by decreasing the $\mathrm{pH}$ value in the colon, which inhibits the production of secondary bile acids, which cause cancer.

\section{CONCLUSION}

Oligosaccharides compound had been successfully isolated from local honey Apis spp. and Trigona spp. honey bees with yields of $3.78 \%$ and $2.21 \%$, respectively. The total sugar content of KR and KL honey oligosaccharides were $1287.82 \pm 3.11 \mathrm{mg} / \mathrm{L}$ and $336.54 \pm 0.00 \mathrm{mg} / \mathrm{L}$, respectively. The reduced sugar content of KR and KL honey oligosaccharides were $387.33 \pm 8.08 \mathrm{mg} / \mathrm{L}$ and $144.67 \pm 8.08 \mathrm{mg} / \mathrm{L}$, respectively. The TPC results showed that the maximum bacterial growth of Lactobacillus acidophilus for KR was $(8.00 \pm 0.28) 108 \mathrm{cfu} / \mathrm{mL}$ after 24 hours of inoculation, and $(7.35 \pm 0.78) 108 \mathrm{cfu} / \mathrm{mL}$ for KL after 48 hours of inoculation.

\section{REFERENCES}

[1] Food Agriculture Association (FAO). Technical Meeting on Prebiotics. 2007. Rome: FAO; 12 p.

[2] Scholz-Ahrens KE, Ade P, Marten B, Weber $\mathrm{P}$, Timm W, et al. Prebiotics, probiotics, and synbiotics affect mineral absorption, bone mineral content, and bone structure. J Nutr. 2007 Mar;137(3 Suppl 2):838S-846S. doi: 10.1093/jn/137.3.838S. PMID: 17311984.

[3] Anderson J.W., Gilliland S.E. Effect of fermented milk (yogurt) containing Lactobacillus acidophilus L1 on serum cholesterol in hypercholesterolemic humans. J Am Coll Nutr.18(1), 1999, pp.43-50. doi: 10.1080/07315724.1999.10718826.

[4] Schley, P.D. \& Field, CJ. Immune-enhancing effects of dietary fibres and prebiotics. The British J Nutr. 2002 May; 87 Suppl 2:S221-30. doi: 10.1079/BJNBJN/2002541. PMID: 12088522 .

[5] Reddy D.S., Hamid R \& Rao C.V. Effect of dietary oligofructose and inulin on colonic preneoplastic aberrant crypt foci inhibition. Carcinogenesis. 18(7), 1997,pp 1371-1374. doi: 10.1093/carcin/18.7.1371. PMID: 9230282 .

[6] National Honey Board (NHB). Honey information kit of the food and beverage industries. 2021. Longmont, CO: National Honey Board. Available from: https://honey.com/

[7] Kajiwara S., Gandhi H., Ustunol Z. Effect of honey on the growth of and acid production by human intestinal bifidobacterium spp.: an in vitro comparison with commercial oligosaccharides and inulin. J Food Prot. 65(1), 2002, pp. 214-218. doi: 10.4315/0362028x-65.1.214. PMID: 11808799.

[8] Shin H.S., Ustunol Z. Carbohydrate composition of honey from different floral sources and their influence on growth of selected intestinal bacteria: An in vitro comparison. Food Res Int. 38(6), 2005,pp 721 - 728. doi:10.1016/j.foodres.2005.01.007.

[9] Sanz M.L., Polemis N., Morales V., Corzo N., Drakoularakou A., Gibson G.R., Rastall R.A. In vitro investigation into the potential 
prebiotic activity of honey oligosaccharides. $\mathrm{J}$ Agric Food Chem. 53(8),2005, 2914-2921. doi: 10.1021/jf0500684. PMID: 15826039.

[10] Karimah U., Anggowo Y.N., Falah S., Suryani. isolasi oligosakarida madu lokal dan analisis aktivitas prebiotiknya. J Gizi dan Pangan. 6(3), 2011,pp. 217-224. doi: 10.25182/jgp.2011.6.3.217-224

[11] Fatma I.I., Haryanti S., Suedy S.W.A. Uji kualitas madu pada beberapa wilayah budidaya lebah madu di kabupaten pati. J Bio. 6(2), 2017, pp. 58-65. Available from: https://ejournal3.undip.ac.id/index.php/biolog i/article/download/19538/18528

[12] Morales, V., Sanz, M.L., Olano, A., Corzo, N. Rapid separation on activated charcoal of high oligosaccharides in honey. Chroma. 64, 2006, pp.233-238. doi:10.1365/s10337-006-0842-6

[13] Aso K., Watanabe T., Yamao K. Studies on honey: on the sugar composition of honey. Tohoku J Agri Res. 11(1), 1960, pp. 101-108. Available from: http://hdl.handle.net/10097/29305

[14] Bounias M. N-(1-naphthyl)ethylenediamine dihydrochloride as a new reagent for nanomole quantification of sugars on thin-layer plates by a mathematical calibration process. Anal Biochem. 106(2), 1980, pp.291-295. doi: 10.1016/0003-2697(80)90523-0. PMID: 7446996 .

[15] Dubois M., Gilles K.A., Hamilton J.K., Rebers P.A., Smith F. Colorimetric method for determination of sugars and related substances. Anal Chem. 28(3), 1956,pp. 350-356. doi: 10.1021/ac60111a017

[16] Miller, G.L.. Use of dinitrosalicylic acid reagent for determination of reducing sugar. Anal Chem. 31(3), 1959, pp. 426-428. doi: $10.1021 / \mathrm{ac} 60147 \mathrm{a} 030$

[17] Association of Official Analytical Chemists (AOAC). official methods of analysis of association of official analytical chemists $18^{\text {th }}$ edition. 2005. AOAC, Inc. Washington.

[18] United States Department of Agriculture Animal and Plant Health Inspection Service (USDA-APHIS). standard operating policy/procedure standard bacterial plate count. 2015. Ames, IA.

[19] Kakutani, T., Inoue, T., Tezuka, T., \& Maeta Y. Pollination of strawberry by the stingless bee,Trigona minangkabau, and the honey bee,Apis mellifera: An experimental study of fertilization efficiency. Res Popul Ecol. 35(1), 1993, pp. 95-111 doi: 10.1007/BF02515648

[20] Anklam E. Review of analytical methods to determine the geographical and botanical origin of honey. Food Chem. 63(4), 1998,pp. 562-594. doi: 10.1016/S0308-8146(98)000570

[21] Bao Z., Duan S., Zhang Z., Xing H., Su B., Yang Q., et al. Adsorption separation of raffinose from sucrose by activated carbon: equilibrium, kinetics and dynamic breakthrough. Separation Sci and Technol, 51(10), 2016, pp. 1636-1644. doi: 10.1080/01496395.2016.1177075

[22] Ruiz-Matute A.I., Brokl M., Soria A.C., Sanz M.L., Matinez-Castro. Gas chromatographicmass spectrometric characterisation of tri- and tetrasaccharides in honey. Food Chem, 120, 2010, pp. 637-642. doi: 10.1016/j.foodchem.2009.10.050

[23] Amin F.A.Z., Sabri S., Mohammad S.M., Ismail M., Chan K.W., Ismail N., et al. Therapeutic properties of stingless bee honey in comparison with European bee honey. Adv in Pharmacol and Pharm Sci. 2018 Dec; 2018: 12 p. doi: 10.1155/2018/6179596 